\title{
Combination Radioimmunotherapy Strategies for Solid Tumors
}

\author{
Javeria Zaheer ${ }^{1,2,+}$, Hyeongi Kim ${ }^{1,+}{ }^{+}$, Yong-Jin Lee ${ }^{1}$, Jin Su Kim ${ }^{1,2, *}$ and Sang Moo Lim ${ }^{1}$ \\ 1 Division of RI application, Korea Institute of Radiological and Medical Sciences, (KIRAMS), 75 Nowon-ro, \\ Nowon-gu, Seoul 01812, Korea; javeria24@kirams.re.kr (J.Z.); erwin.hyeongi@gmail.com (H.K.); \\ yjlee@kirams.re.kr (Y.-J.L.); smlim328@kirams.re.kr (S.M.L.) \\ 2 Radiological and Medico-Oncological Sciences, University of Science and Technology (UST), 75 Nowon-ro, \\ Nowon-gu, Seoul 01812, Korea \\ * Correspondence: kjs@kirams.re.kr; Tel.: +82-2-970-1661 \\ + These authors contributed equally to this work.
}

Received: 12 October 2019; Accepted: 6 November 2019; Published: 8 November 2019

\begin{abstract}
Combination radioimmunotherapy is an emerging approach for the treatment of solid tumors where radio immunotherapy alone has proven to be reasonably ineffective. Radioimmunotherapy (RIT) using monoclonal antibodies (mAbs) labeled with radionuclides is an attractive approach for cancer treatment because tumor-associated $\mathrm{mAbs}$ with cytotoxic radionuclides can selectively bind to tumor antigens. However, due to various limitations, mAbs cannot reach solid tumors, consequently reducing RIT efficacy. Combination RIT is a pragmatic approach through which the addition of drugs or other agents not only help mAbs to reach the targeted site but also improves its efficacy. Thus, the combination of drugs or moieties with RIT can be applied to overcome the barriers that RIT faces for solid tumors. This review covers the RIT approach, along with the mechanism of action of mAb used in RIT, limitations of solid tumors, and strategies that can be used in combination RIT to enhance the treatment regimen for solid tumors.
\end{abstract}

Keywords: radioimmunotherapy; solid tumors; monoclonal antibody; extracellular matrix; cell-to-cell junctions; interstitial pressure; immune suppressive environment

\section{Introduction}

Radioimmunotherapy (RIT) in nuclear medicine involves the injection of a radioisotope-labeled monoclonal antibody $(\mathrm{mAb})$, using intravenous or intratumoral injection [1], to treat cancer [2-4]. With RIT, radionuclides are carried directly toward the tumor and emit radiation-induced double strand DNA breaks, finally inducing cell death [5,6]. RIT such as ${ }^{131}$ I-tositumomab (Bexxar, GlaxoSmithKline, Philadelphia, PA 19112, USA) [7], ${ }^{131}$ I-rituximab (Rituxan; Genentech, CA, USA) [8], and ${ }^{90}$ Y-ibritumomabtiuxetan (Zevalin; Biogen Idec, Cambridge, MA, USA) $[9,10]$ were administered for treatment of hematological tumors. However, RIT for solid tumor has been less applied in clinics, due to barriers created by tumor microenvironments, such as tumor heterogeneity, abnormal structures of the tumor vessels, highly fibrotic or desmoplastic tumors, absence of functional lymphatics, and high interstitial fluid pressure (IFP) within the tumor [11]. Thus, combination strategies of RIT were investigated for solid tumors. A number of solutions, such as fractionated doses [12], mAb pre-targeting [13-16], and affibody [17], were investigated to improve the efficacy of RIT. Fractionated RIT using ${ }^{90}$ Y-clivatuzumab was performed to treat patients with stage III/IV pancreatic ductal carcinoma [12]. Regarding mAb pre-targeted strategy, CD38 pre-targeted RIT was performed for B-cell tumors [14]. Another approach to enhance the penetration of $\mathrm{mAb}$ was the use of small target protein and then an antibody such as an affibody [17]. 
In this paper, we review the basic mechanism, limitations, and combination strategies of RIT used to enhance its therapeutic efficacy for solid tumors.

\section{Isotopes for RIT}

Various radioisotopes have been used for RIT. For example, bulky tumors can be treated with radionuclides that emit long-ranged $\beta$-rays, such as ${ }^{131} \mathrm{I}$ or ${ }^{90} \mathrm{Y}$, whereas small clusters of cells or tumors can be effectively targeted by $\alpha$-particles [18] or short range $\beta$-rays [4]. A schematic of RIT is shown in Figure 1. Characteristics of radionuclides for RIT are shown in Table 1. Examples of commercialized mAbs used in RIT are listed in Table 2.

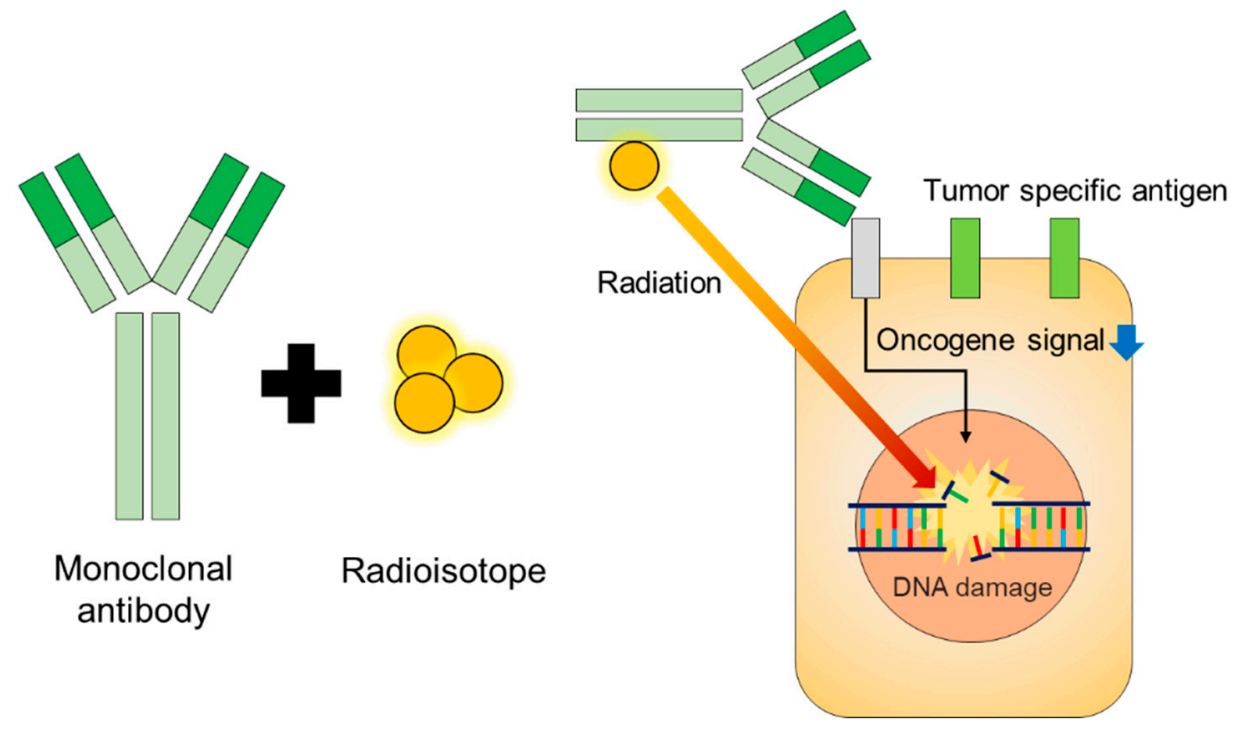

Figure 1. Schematic of radioimmunotherapy (RIT). RIT delivers radiation directly to the tumor-specific antigen of a specific cancer type. The downward blue arrow shows downregulated oncogene signals

Table 1. Radionuclides for RIT.

\begin{tabular}{cccc}
\hline Radioisotopes & Max Range (in Water) & Half-Life & Max Energy (keV) \\
\hline$\beta$-emitter & & & \\
${ }^{67} \mathrm{Cu}$ & $2.1 \mathrm{~mm}$ & $61.9 \mathrm{~h}$ & 575 \\
${ }^{90} \mathrm{Y}$ & $11.3 \mathrm{~mm}$ & $64.1 \mathrm{~h}$ & 2284 \\
${ }^{131} \mathrm{I}$ & $2.3 \mathrm{~mm}$ & 8.0 days & 606 \\
${ }^{177} \mathrm{Lu}$ & $1.8 \mathrm{~mm}$ & 6.7 days & 497 \\
$\alpha$-emitter & & & \\
${ }^{211} \mathrm{At}$ & $<50 \mu \mathrm{m}$ & $7.2 \mathrm{~h}$ & 586 \\
${ }^{213} \mathrm{Bi}$ & $<50 \mu \mathrm{m}$ & $45.6 \mathrm{~min}$ & 5870 \\
${ }^{225} \mathrm{Ac}$ & $<50 \mu \mathrm{m}$ & $240 \mathrm{~h}$ & 5830 \\
${ }^{223} \mathrm{Ra}$ & $<100 \mu \mathrm{m}$ & 11.4 days & 5979 \\
\hline
\end{tabular}

Table 2. Monoclonal antibodies and their tumor-specific antigen used for RIT.

\begin{tabular}{cc}
\hline Monoclonal Antibody & Targeted Site \\
\hline Trastuzumab (Herceptin, Roche, Basel, Switzerland) & HER2 \\
Bevacizumab (Avastin, Genentech, CA, USA) & VEGF-A \\
Cetuximab (Erbitux, Kenilworth, NJ, USA) & EGFR \\
Rituximab (Rituxan, Genentech, CA, USA) & CD20 \\
Tositumomab (Bexxar, Genentech, CA, USA) & CD20 \\
Ibritumomab tiuxetan (Zevalin, Biogen Idec, Cambridge, MA, USA) & CD20 \\
\hline
\end{tabular}




\section{Mechanism of Therapeutic Monoclonal Antibodies}

Therapeutic mAbs work by targeting specific cell-surface receptors and destroying cancer cells via various mechanisms [19]. Cancer cells use oncogene protein signaling, such as EGFR and HER-2, for survival and proliferation. Therapeutic $\mathrm{mAbs}$ are designed to bind with the tumor-specific antigen or oncogene proteins, such as EGFR, Her2, or CD20. For example, Trastuzumab binds to HER2 receptor directly [20] and inhibits the tyrosine kinase signal. This mechanism reduces tumor growth, proliferation, and cell survival signal. Rituximab binds to the CD20 membrane, thereby inducing cellular apoptosis signaling [21].

The mechanism of therapeutic $\mathrm{mAb}$ originates from its various functions. A mAb neutralizes the pathophysiological function of the target moiety by binding to the surface-expressed receptor, facilitating antibody-dependent cellular cytotoxicity (ADCC), antibody-dependent phagocytosis (ADCP), and complement-dependent cytotoxicity (CDC) [22]. Figure 2 depicts the mechanism of action of $\mathrm{mAb}$. The $\mathrm{mAb}$ binds to the target antigen by its $\mathrm{Fv}$ domain, which inhibits the cellular signaling of target cells. Thus, the targeted tumor cell becomes resensitized to cytotoxic agents. Triggering the cytotoxic immune effector cells, like dendritic cells and macrophages, is followed by the process of immune-effector cell lysis of the target cell, as in ADCC or by phagocytosis (ADCP). Similarly, C1 of the CDC process binds to the antibody-antigen complex and initiates a complex process to target cell lysis [23].

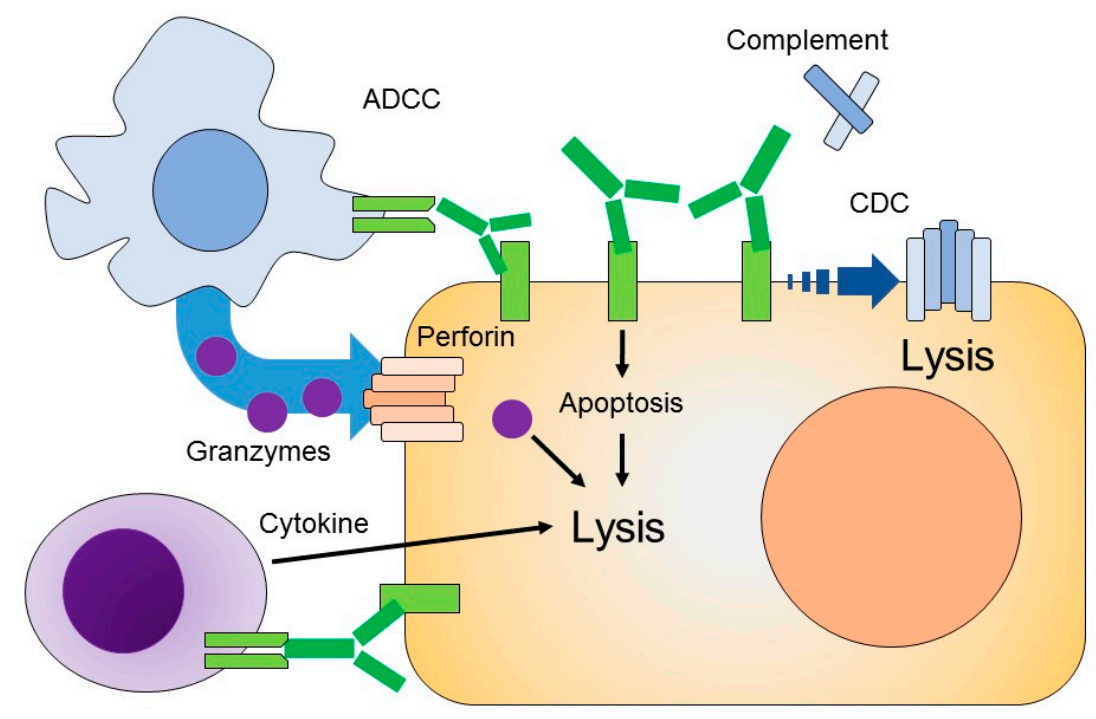

Figure 2. Mechanism of action of an $\mathrm{mAb}$. The $\mathrm{mAb}$ binds to its targeted antigen and provokes antibody-dependent cellular cytotoxicity (ADCC) and a complement-dependent cytotoxicity (CDC) response. ADCC includes (natural killer) NK cells, which release granzymes and cytotoxic agents that are responsible for cell lysis. The $\mathrm{Fc}_{\mathrm{c}}$ region of $\mathrm{mAb}$ may also bind to soluble protein $\mathrm{C} 1 \mathrm{q}$ to promote a cascade reaction that eventually forms a membrane attack complex, as in the CDC-mediated response. Membrane attack complex (MAC) is responsible for disrupting cell membrane and inducing cell lysis.

\subsection{Antibody-Dependent Cellular Cytotoxicity (ADCC)}

The ADCC and ADCP response is elicited when the immune cell binds to the Fc region of the antibody, while the antibody is targeted to the antigen. In this way, mAb mediates the ADCC response by collaboration with cytotoxic cells like natural killer cells (NK) [24] and macrophages [25]. NK cells bear Fc gamma receptors on their surfaces and release cytotoxic agents, like perforin and granzymes, upon activation. Perforin binds to the target cell's plasma membrane and creates a pore [26], and granzymes induce apoptosis and fragmentation of cellular DNA [27]. NK cells are activated by binding with the Fc region of immunoglobulins. Apart from releasing the cytotoxic mediator that is responsible 
for lysis of the tumor cells, NK cells secrete interferon- $\gamma$, thus playing a role in the recruitment of adaptive immune cells [28].

\subsection{Complement-Dependent Cytotoxicity (CDC)}

The mAb binds antigens via the Fv region, where the Fc domain may bind to soluble protein complex $\mathrm{C} 1 \mathrm{q}$, leading to the activation of complement cascade that eventually causes cell death. The antigen-targeted $\mathrm{mAb}$ and complement complex, such as $\mathrm{C} 5 \mathrm{~b}$ to $\mathrm{C} 9$, are deposited at the target cell's membrane, forming a cylindriacal membrane attack complex (MAC). MAC disrupts the cell membrane of target cells and is responsible for lysis of tumor cells [28].

\section{Mechanism of Currently Commercialized mAb for Radioimmunotherapy}

\subsection{Trastuzumab}

The transmembrane tyrosine kinase receptors, which include the HER family, regulate cell survival and growth. They are responsible for cell adhesion, migration, and differentiation. Ligand binding generally induces the tyrosine kinase domain, and the receptors are activated by both homodimerization and heterodimerization. Activation may also occur via overexpression of the receptor or by mutation. The overexpression of the HER-2 receptor is mostly observed in breast and gastric cancers. Trastuzumab is the monoclonal antibody composed of two antigen-specific binding sites and rest resembles Fc of immunoglobin $\mathrm{G}(\mathrm{IgG})$. Trastuzumab works via several mechanisms, including (1) preventing HER-2 receptor dimerization, (2) destroying the receptor by endocytosis, and (3) inhibiting the shedding of the extracellular domain and immune activation. Trastuzumab mediates the antibody-mediated cell cytotoxicity by recruiting various effector cells [20,29].

\subsection{Bevacizumab}

Vascular endothelial growth factor (VEGF) is a protein that has angiogenic activity. VEGF was initially purified from fluid released from a tumor and was named $V E G F-A$. The genes of the VEGF family include VEGF- $A, V E G F-B, V E G F-C$, and VEGF-D, and they are found in mammalian genomes, including those of humans. VEGFR is the tyrosine kinase receptor for $V E G F$, which includes a ligand binding extracellular domain, transmembrane domain, and a cytoplasmic domain. Signaling in typical kinase receptor activates Ras (Kristen rat sarcoma) and PI3K (Phosphatidylinositol 3-kinase) pathways. $P L C v$ (Phospholipase v, PKC (Protein kinase C) and MAPK (Mitogen activated protein kinase) pathways have also been observed to be activated by VEGF bound to VEGFR-2. Bevacizumab (anti-VEGF-A humanized monoclonal antibody), commercialized under the name of Avastin ${ }^{\circledR}$, (Genentech, CA, USA) works via anti-VEGF-A/VEGFR therapy. It is approved for colorectal, breast, renal, and small-cell lung cancer and glioblastoma therapy [30]. Clinical data for bevacizumab with other chemotherapeutic agents in the CAIRO2 and PACCE trials also showed lower effectiveness in treatment and survival studies [31,32]. Bevacizumab has been tested in triple negative breast cancer in three steps: (1) pre-targeted approach for fast clearance, (2) low toxicity, and (3) higher therapeutic efficacy [33]. Using an animal model, the researchers stated that in the normal state, the blood vessels remain relatively independent of the VEGF level; in contrast, immature tumor vasculature and associated vessels spared by pericytes were observed to disrupt the VEGF expression level [34]. However, the reoccurrence of the tumor model in a microscopy study was also observed, and the mechanism was described as follows: continuous anti-VEGF therapy leaves behind the intact basement membrane that serves as a scaffold and enables the rapid regrowth of the vasculature [35]. In addition to the increase in the tumor vasculature, VEGF overexpression has been associated with the vascular permeability, which results in an elevated level of interstitial fluid pressure, insufficient blood flow, and poor to uneven perfusion. These factors constitutively hinder drug delivery, especially $\mathrm{mAb}$. The proposition of normalization has gathered research support, where pruning of the immature abnormally functioning vessel sprouts improves delivery of cytotoxic drugs. A possible mechanism explaining this function is the release 
of a vasodilator mediator, like nitric oxide or prostacyclin, upon downstream signaling generated via VEGF-2 activation by VEGF. Anti-VEGF therapy thus restricts the vasodilators and produces relative vasoconstriction that eventually limits the tumor blood volume. Apart from these mechanisms, another factor affecting apoptosis in tumor cells was examined by using anti-VEGF therapy via NRP-1 (Neuropilin-1) and NRP-2 (Neuropilin 2). VEGF promotes survival signals in breast carcinoma [20,30]. However, the antibody penetration into the tumor with antiangiogenic therapy is controversial. The additive effect of bevacizumab was not observed during radioimmunotherapy [36]. Arjaans et al. showed that blood vessels are normalized via bevacizumab treatment, which is an antiangiogenic drug that does not improves antibody uptake but decreases mean vascular density [37]. Therefore, extensive research is needed to evaluate normalization and drug delivery via anti-angiogenic therapy for clinical use [38].

\subsection{Cetuximab}

Cetuximab works by blocking the epidermal growth factor receptor (EGFR). The EGFR is a transmembrane glycoprotein that is composed of an extracellular ligand-binding domain, a transmembrane domain, and an intracellular tyrosine kinase domain. The EGFR plays an important role in the growth and sustenance of many human tumors and is expressed on the epithelial surface of the breast, brain, and prostate cancer. This receptor binds to EGFR ligands and triggers a cascade of signaling. Cetuximab is approved in irinotecan-intolerant advanced metastatic colorectal cancer and second line therapy with squamous cell carcinoma of the head and neck. Cetuximab antitumor efficacy is categorized into two groups: EGFR signal transduction and tumor antigen-targeted cellular immunity. Cetuximab has been shown to be effective in both monotherapy and in combination with other agents and chemotherapeutic drugs, especially for tumors with wild-type KRAS activity and metastatic colorectal cancer. Cetuximab efficiently treats metastatic colorectal cancer, but the response-rate values are still insignificant; therefore, targeted therapies are critically important and should be applied to patients with the purpose of optimizing treatment. Markers in EGFR that include both clinical and biological are agents for forecasting the response of cetuximab. KRAS is the most efficient biomarker, and patients with KRAS mutations benefit from cetuximab-based treatment. The responses and reactions of other biomarkers, like BRAF (member of Raf-family (rapidly activated fibrosarcoma)), NRAS (Neuroblastoma viral Ras Oncogene homolog), PIK3CA (Phosphotidyl inositol-4,5-Bisphosphate 3-Kinase Catalytic Subunit Alpha), and exon 20 are currently being studied [39].

Tumor cells use the immune escape mechanism to elude mAb-induced antitumor response, and cetuximab may provide assistance with differential clinical reactions to tumor antigen (TA)-targeted mAb immunotherapy. In some cases, the combination of TA-specific mAb-based immunotherapy and administration of cytokines or immune adjuvants may benefit patients. EGFR transduction is complex, and tumor cells can avoid effects of cetuximab. Despite hampering EGFR and renewing the ADCC reaction, cetuximab can also restrict articulation of VEGF and cancer angiogenesis. Basic and clinical research should develop cetuximab-based therapies, as existing predicting markers are unsatisfactory $[39,40]$.

\subsection{Rituximab}

Rituximab is essential in the treatment process of malignant tumors, particularly of various B-cell malignancies. In some cases, rituximab alone can produce highly positive reactions and long-term abeyance, whereas, in others, it directly enhances the response rate and overall survival. Despite its role as part of the treatment for tumors, it does not work universally for all patients. Various reactions and instances of resistance have been observed. Without immune-effector mechanisms, rituximab can cause death of malignant cells in vitro; however, this differs from one cell line to another. Rituximab works via (1) direct signaling-induced cell death, (2) complement-mediated cellular cytotoxicity, and (3) antibody-dependent cellular cytotoxicity. Changes that are recognized in the response of rituximab in vitro include hindrance of p-38 mitogen-activated protein kinase, nuclear 
factor- $\mathrm{KB}(\mathrm{NF}-\mathrm{\kappa B})$, extracellular signal-regulated kinase 1/2 (ERK 1/2), and AKT anti-apoptotic survival signaling pathways, though rituximab is not associated with genetic changes in the CD20 molecule but is connected with changes in signaling. Detection of signaling changes of rituximab response requires cross-linking of rituximab with other antibodies. However, whether it proves useful in clinical therapy has not been determined. Large cell lymphoma and mantle cell lymphoma are less sensitive to rituximab therapy; follicular lymphoma cells are more sensitive. Various studies showed that cell-mediated cytotoxicity (CMC) could aid in the antitumor activity of rituximab in the extravascular and intravascular compartments. CMC can result in quick cell death of rituximab-coated target cells, and is a basic mechanism of action for antibody therapy in some animal models; however, the degree to which it is effective is not yet clear, but the clinical capability is strong enough to promote the development of next-generation CD20. The most promising evidence that ADCC is involved in the clinical response to rituximab therapy was produced from correlative studies illustrating an association between polymorphisms on CD16 and the clinical response to rituximab. Studies point to more than one mechanism playing a role in therapy, including an increase in complement inhibitory molecules, decreased expression of CD20, and enhanced expression of anti-apoptotic molecules. Identification of rituximab mechanisms may not be applicable to all anti-CD20 mAbs, as emerging evidence revealed that not all anti-CD20 mAbs are alike. Clinical trials based on these data include evaluation of antibodies with an enhanced ability to signal and mediate CMC and ADCC. Such findings have to be supported by rigorous correlative analysis, and will add to our understanding of the various mechanisms of action of rituximab in different settings [21].

\subsection{Immune Suppression Checkpoint Inhibitor}

The mAbs that target checkpoint proteins include PD-L1 on tumor cells, PD-1, and CTLA4 on T cells. Examples of PD-1 inhibitors include pembrolizumab (keytruda ${ }^{(\mathrm{Rx})}$ ), nivolumab (opdivo ${ }^{(\mathrm{Rx})}$ ), and cemiplimab (libtayo). Examples of PD-L1 inhibitor include atezolizumab (tecentriq ${ }^{(\mathrm{Rx})}$ ), avelumab (bavencio $^{(\mathrm{Rx})}$ ), and durvalumab (Imfinzi ${ }^{(\mathrm{Rx})}$ ). An example of the CTLA-4 inhibitors is ipilimumab (yervoy ${ }^{(R x)}$ [41]. The immune system maintains immunity via immune surveillance and editing, where $\mathrm{T}$ cells continually patrol to find and kill antigens. Several factors are responsible for immune suppression by tumor cells. The most commonly described factors are the loss of tumor antigen and cytotoxicity resistance development through which immune $\mathrm{T}$ cells, when near tumor cells, are unable to recognize the antigen. Immune suppression checkpoint inhibitor enhances $\mathrm{T}$ cell immunity by modulating the tumor cell and immune cell interaction [42].

\section{Limitation of RIT for Solid Tumors and Combination RIT Strategies}

Theoretically, RIT could be a good candidate for antitumor therapy. However, clinical application of RIT for solid tumors has been limited due to the presence of external and internal barriers during RIT for solid tumors. External barriers include high interstitial pressure [36,43], extracellular matrix (ECM) [44], tight junctions [45], and an immunosuppressive environment [46]. Internal barriers include the modulation of the tumor signal pathways by drugs or medicine targeting the hallmarks of cancer [47]. In this review, we focused on the external barriers to RIT. Figure 3 depicts a schematic of the factors limiting RIT application for solid tumors.

Various preclinical data about overcoming the limitations to RIT delivery show promise for future clinical trials. In all instances of overcoming the limitations of RIT in solid tumors, RIT demonstrates a promising therapeutic strategy for cancer treatment $[48,49]$. Herein, we also reviewed the possible strategies for enhancing the effect of RIT for solid tumors. Figure 4 shows existing and potential strategies for RIT. 


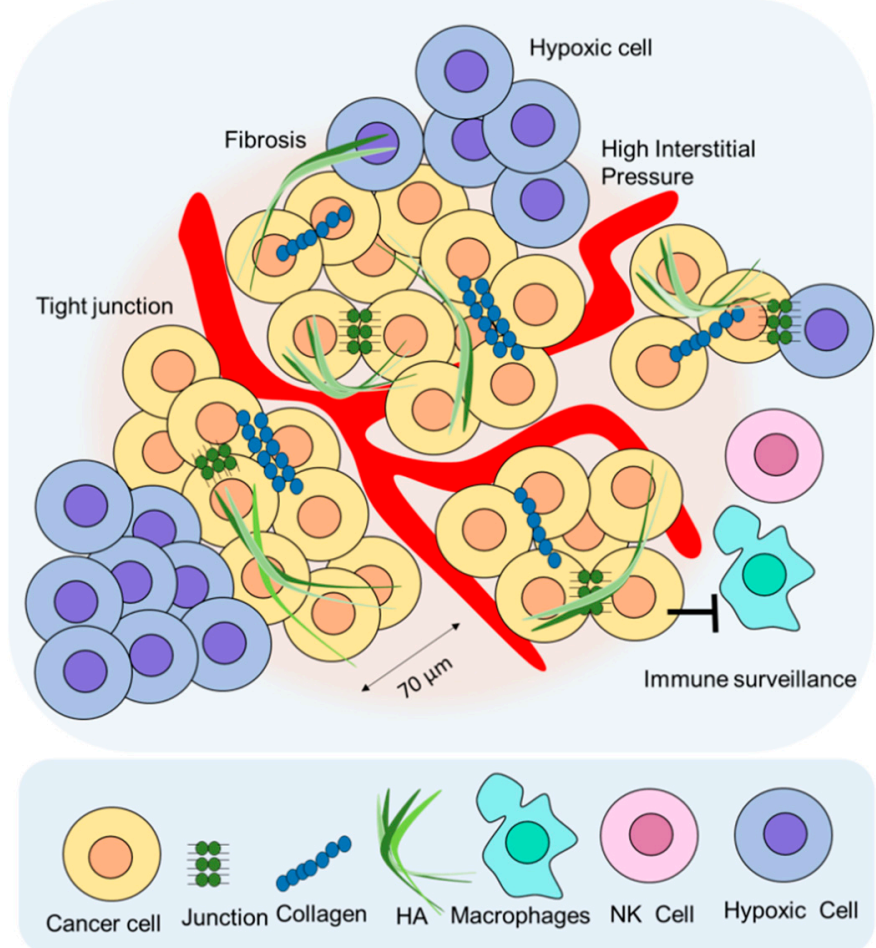

Figure 3. Limitations of RIT in terms of drug delivery. The extracellular matrix (ECM) is composed of collagen, hyaluronic acid (HA), and fibroblasts that hinder drug delivery. Tight junctions and high interstitial pressure are some of the restrictions to RIT delivery in solid tumors.

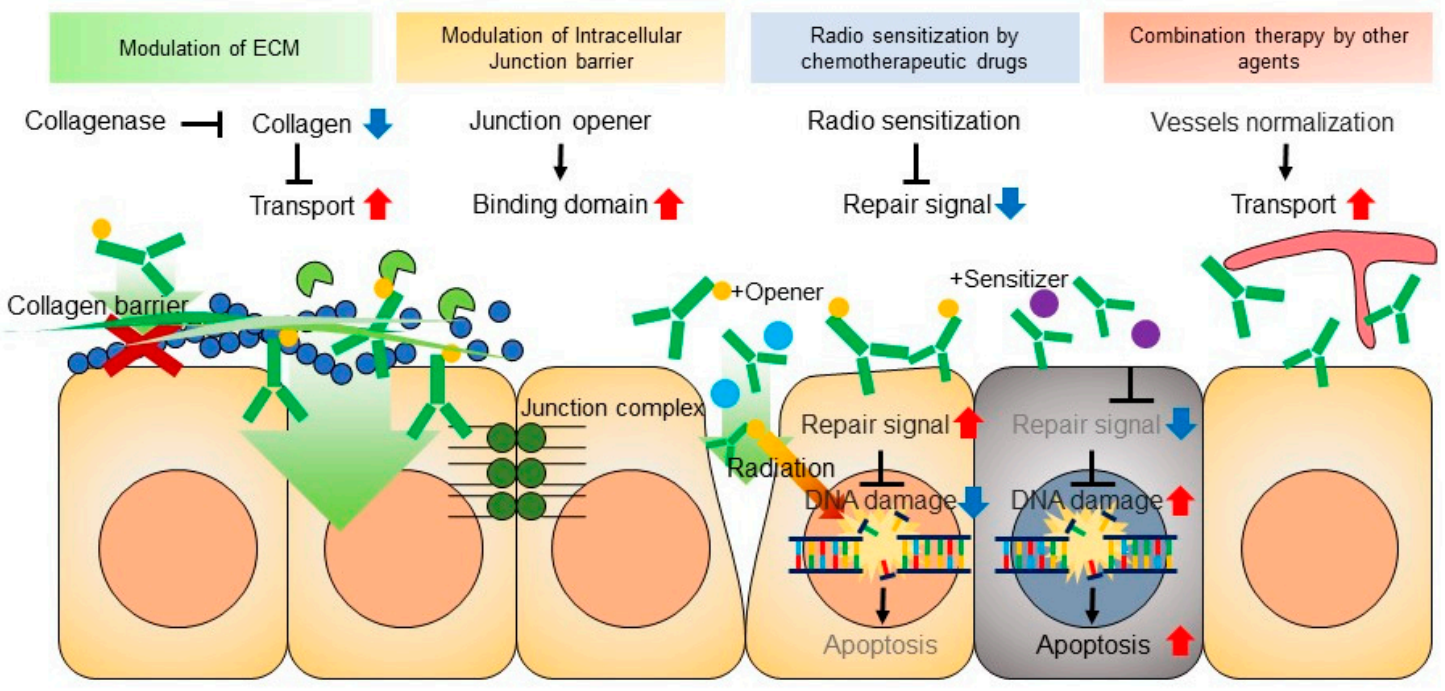

Figure 4. Strategies for combination RIT. The ECM was found to present a considerable barrier to $\mathrm{mAb}$ penetration; therefore, ECM-degrading elements are crucial when designing a combinational RIT strategy. Another approach involves liberating tight cell-cell junctions by using drugs that target junctional proteins. Chemotherapeutic agents are cytotoxic agents that are commonly applied in combination RIT. Cell damage reduces the solid stress, which eventually reduces the interstitial pressure and improves RIT efficacy. The combination of RIT with other agents enhances drug transport by vessel normalization or by agents increasing antitumor immunity. The downward blue arrow shows decreased collagen and downregulated oncogene signaling. The upward red arrow shows improve transport and upregulated oncogene signaling. 


\subsection{Extracellular Matrix (ECM)}

The tumor-associated ECM is one physical barrier to mAb transport. Glycoproteins and polysaccharides are the major components of the ECM that collectively join to produce the basement membrane [50]. The basement membrane separates the epithelial, endothelial, and interstitial matrix; it is composed of type IV collagen, laminins, and linker proteins, such as nidogens and fibronectin. The interstitial matrix is composed of fibrillary collagens, proteoglycans, and glycoproteins, like tenascin-C and fibronectin, and functions in tissue flexibility. The ECM anchors the basement membrane to maintain tissue polarity. ECM may also be involved in cell migration through the ECM and act as a barrier. The ECM contains components that bind to growth factor receptors, such as heparin sulfate and hyaluronic acid. The ECM can remodel in different tissues, depending upon the context. Another feature of ECM in TME is the cell-ECM interaction facilitating cell rearrangement, realignment, or lysis [44]. Any dysregulation of ECM remodeling enzymes can lead to a disease state and is regarded as a cancer hallmark [46,51]. Highly expressed ECM could increase solid-stress (SS), and this SS interrupts drug transport of $\mathrm{mAb}$ and macromolecules [52].

ECM-degrading enzymes have shown promise. In an osteosarcoma model with highly expressed collagen, drug transport was improved by collagen-degrading enzyme collagenase [53]. Enhanced penetration of $\mathrm{mAb}$ in human osteosarcoma xenografts was achieved after the injection of collagenase [53]. Another ECM component, hyaluronan, was reported to promote cell progression and restrict the binding of trastuzumab to its receptor [54]. By developing drugs that inhibit hyaluronan, trastuzumab binding to its receptor can be enabled. The use of carriers, such as hydrogel-based drug delivery with collagenase and trastuzumab localized delivery, have shown therapeutic potential for drug penetration by the degradation of the ECM [55]. ECM remodeling by the oncolytic vaccinia virus enhanced the efficacy of immune-checkpoint blockade [56]

\subsection{Cell-to-Cell Junctions}

Cell-to-cell junctions regulate the permeability of the two layers of cells and provide a method of communication between cells and the plasma membrane [57]. Tight junctions are the guard of paracellular pathways. However, cell-to-cell junctions in cancer reduce drug transport [53]. Epithelial junctions reduce transport of trastuzumab and cetuximab in solid tumors [58]. Tight junctions reduce the killing effect by trastuzumab [59]. Wang et al. showed that reducing the tight junction via adenovirus serotype 3 could increase the anticancer effect of trastuzumab in a breast-cancer xenograft model [59]. Similarly, desmoglein-2, an epithelial protein, served as the primary attachment receptor for human adenovirus [58]. The authors derived a protein from human adenovirus that targeted desmoglein-2 and named it junctional opener- 1 (JO-1). JO- 1 for $\mathrm{mAb}$ was effective in the treatment of a solid tumor.

\subsection{High Interstitial Pressure}

Solid tumors are composed of cancer cells tightly packed together with abrupt and leaky blood vessels and lymphatic vessels. The leaky nature of blood vessels and the drainage of lymphatic vessels increase the interstitial pressure in tumors. Solid tumors have high interstitial fluid pressure (IFP) [60]. Tumor cells generate solid stress, and this stress compresses the surrounding blood vessel and increases the IFP and microvascular pressure [61]. This increase creates a barrier to drug transport. Due to the increase in interstitial pressure, the uptake of therapeutic agents is limited $[36,43,62]$. The mechanism underlying high IFP is not clearly understood, but various factors are thought to be involved, including the permeable environment of the vessels, irregularities associated with lymph vessels, and interstitial space confined by the fibroblast of the stroma [60]. Human pancreatic cancer orthotropic xenograft mice had higher IFP than in a normal pancreatic tumor group [63]. Solid tumors were found to have a high IFP [64]. Both hydrostatic and osmotic pressure increase in solid tumors [65,66]. The molecular weight of anticancer drugs or proteins are relatively large compared to those of glucose or oxygen. 
The uptake of anticancer drugs into the tumor area is highly intermittent due to elevated IFP [60]. Many attempts were made to overcome this barrier. High-intensity focused ultrasound (HIFU) provided enhanced uptake of drug by disruption of the stroma [67]. Combination of RIT with HIFU showed higher penetration of $\mathrm{mAb}$ [68]. The combination of RIT with paclitaxel also produced enhanced accumulation of $\mathrm{mAb}$ in tumor tissue [36]. Tanexe induced apoptosis via disruption of the microtubular network associated with the reduction in interstitial pressure [69].

\subsection{Immune Surveillance}

Interactions between immune cells and tumor cells produced an immunosuppressive environment, wherein the host's own immune cells were unable to fight the cancer; rather, they participated in growth signaling, promotion, and differentiation. Immunotherapies emphasize the importance of exploiting the interactions of immune cells to kill the cancer cells [70]. PD-1 is an immune inhibitory receptor that is expressed in immune cells like $\mathrm{T}$ and $\mathrm{B}$ cells; however, cancer cells manage to escape from the immune system using checkpoint proteins such as PD-1/PD-L1 or CTLA-4. These checkpoint proteins have the ability to cheat immune cells [71]. Other authors studied the various mechanisms through which tumor cells suppress the immune system via cell signaling pathway interruption, alter the protein structure that affects regulatory function, or release cytokines and chemokines from various immune cells [72]. These chemokines and checkpoint proteins play a role in cancer progression by altering costimulatory signals and causing a disproportional ratio of regulatory $\mathrm{T}$ cell (Treg) or suppressor T cells (Ts) to effector cells, resulting in impaired tumor-specific immune responses [70]. Many proto-oncogenes function to control and regulate various cellular processes. Mutations in any of these could disrupt signaling cascade pathways, which may lead to tumor cells potentially affecting the cellular machinery and creating immune surveillance [73].

Investigations into immune checkpoint inhibitors represent a new horizon in anticancer treatment, with James p. Allison and Tasuku Honju winning the 2018 Nobel Prize in medicine/physiology for their discovery of cancer therapy to inhibit negative immune regulation. Checkpoint inhibitor targets PD-1/PD-L1 or CTLA-4 to overcome an immunosuppressive environment [71]. Although immune checkpoint inhibitors are used as a powerful anticancer therapeutic tool, a PD-1/PD-L1- or CTLA-4-negative patient could not achieve good results by using a checkpoint inhibitor. Abdul et al. showed that blocking PD-L1 combined with irradiation increased antitumor efficacy in pancreatic ductal adenocarcinoma; radiation with anti-PD-L1-treated mice dramatically decreased tumor size and increased immunity [74]. Demaria showed that tumors that are nonresponsive to immune checkpoint inhibitors become responsive after radiation therapy, suggesting radiotherapy sensitizes the immunotherapy. For tumors that express high levels of PDL-1, higher doses of radiation may kill these cells [75].

Although no report has been published on the levels of PD-1, PD-L1, or CTLA-4 during RIT, the effect should be investigated, since RIT carries radiation in combination with $\mathrm{mAb}$.

\subsection{Hypoxia}

Cancer cells are crowded and compete with normal cells for the supply of oxygen. A limited supply of oxygen to the cancer cell drops the physiological oxygen level and creates a hypoxic microenvironment for tumor cells, the severity of which depends upon the tumor type.

Theoretically, the supply of oxygen is about $70 \mu \mathrm{m}$ to less than $90 \mu \mathrm{m}$ from the disrupted vessel produced in the tumor microenvironment. Any area beyond that, approximately $100 \mu \mathrm{m}$ from the vessel or with no direct contact with capillaries, is considered hypoxic. Hypoxia is one of the challenging limitations in terms of the radiation treatment. Molecular oxygen is a strong radio sensitizer that captures electrons through the absorption of energy from the radiation source, and $\mathrm{O}^{2}$ plays a part in the DNA damage process [76,77]. In terms of treatment concerning radiation, the nature of the oxygen mechanism is explained by the oxygen enhancement ratio (OER). The OER is the ratio of radiation doses of hypoxic to aerated conditions that produces the same biological effect. It is thought that the 
oxygen effect is largely intermediately observed under sparsely ionizing radiation, like X-rays used in external beam therapy with $\beta$-radiation, but for severely ionizing radiation like $\alpha$-particle-based radiation therapy, the oxygen effect is negligible. Hence, RIT composed of $\alpha$-particle-based radiation antibody therapy is promising. However, the limitation of $\alpha$-particle-based radiation is its short range that cannot reach hypoxic regions. So, hypoxia generates radiation resistance due to reduced therapeutic response, which is why improving $\mathrm{mAb}$ penetration toward the tumor core, deeper into the tumor tissue, is important.

To combat the hypoxic changes, cancer cells alter their metabolism, [33] promote angiogenesis [78], and acquire mobility and metastasis by transitions from an epithelial to mesenchymal phenotype [79]. Hypoxia inducible factor (HIF) is a transcription gene that stabilizes under hypoxia but degrades under a normoxic environment. The degradation of HIF- $\alpha$ is regulated by Von Hippel-Lindau tumor suppressor $(p V H L)$. Structurally, the HIF is a heterodimer, comprised of HIF-1 $\alpha$ and HIF-2 $\alpha$ subunits, and regulated by oxygen concentration. Both subunits share high identity in their functional domain; however, the expression levels are highly variable. The transcriptional gene HIF-1 $\alpha$ plays a responsive role at low oxygen levels, controls vascularization and tumor growth by interacting with enzymes and other transcriptional factors, and is ubiquitously expressed in mammalian cells and tissue. HIF- $2 \alpha$ responds at higher oxygen concentrations and for a longer duration, and it is abundant in endothelial and vascularized cells. Since hypoxia offers resistance to radiotherapy, HIF-1 is considered a therapeutic target in cancer therapeutics $[80,81]$.

\subsection{Combination of RIT with Other Agents}

Combination RIT is the approach where any substance, drug, and moiety that has the potential to either cause apoptosis, decrease interstitial pressure, degrade the ECM, overcome the junctional barrier, overcome immunosuppression or act as a radiosensitizer is used, along with RIT, to enhance RIT delivery and to improve therapeutic efficacy.

A radiosensitizer is a molecule, moiety, or drug that increases the sensitivity of cancer cells to radiotherapy and is nontoxic to normal cells at therapeutic doses [82]. $\mathrm{Ng}$ et al. reported tumor regression and prolonged tumor-free survival when the topoisomerase-inhibition drug, topotecan, was used in combination with RIT in a xenograft model of breast cancer [83]. Milenic et al. reported the potentiation effect of high linear energy transfer radiation with ${ }^{212} \mathrm{~Pb}$ and trastuzumab combined with gemcitabine, which resulted in a median survival of 66 days compared with 34 days without gemcitabine treatment. The study was conducted in xenograft mice bearing LS-174T cells, to study disseminated peritoneal disease [84]. The combined effect of chemotherapy drugs and RIT on gene expression levels was also studied. Yong et al. explored an alkaloid chemotherapeutic, paclitaxel, along with $\alpha$-emitting ${ }^{212} \mathrm{~Pb}$ radiation combined with mAb for HER2, and quantified 84 DNA damage response genes. They reported the killing effect of combination therapy by genes linked to the mitotic spindle checkpoint and BRACA1-(Breast Cancer Gene1) associated genome surveillance complex [85]. In support of combination therapy with paclitaxel as a radiosensitizer, Cividalli et al. explored the enhanced efficacy of paclitaxel in vivo with different doses, reporting a synergistic effect [86]. Apart from combining $\alpha$-emitting radiation, paclitaxel was combined with a $\beta$-emitting, radiolabeled, humanized $\mathrm{mAb}$ in a breast cancer model. Significant potential was observed with combined modality treatment, as explored by Kelly et al. [87]. Kurizaki et al. [88] combined ${ }^{125}$ I-B72.3 with a selective peptide agonist of human C5a (GCGYSFKPMPLaR) (AP), to enhance the efficacy of RIT. Parecoxib (cyclooxygenase-2 inhibitor), as a radiosensitizing agent in combination with RIT, was also reported [89]. The antitumor response with celecoxib, a selective Cox-2 inhibitor, and agonistic anti-CD40 were also used for combinational immunotherapy during treatment of malignant glioma patients and is thus a candidate for RIT [90]. 


\subsection{Improving Pharmacokinetics of $m A b$ with Pre-Targeting}

A critical challenge in the therapeutic use of $\mathrm{mAb}$ is its slow pharmacokinetics characteristic. The size of intact $\mathrm{mAb}$ is $\sim 150 \mathrm{kDa}$, which is larger than other molecules used in nuclear medicine. Since the circulatory residence time is long, which is beneficial because the labeled or unlabeled targeted moiety is in circulation for a longer time, enabling the delivery of the desired therapeutic efficacy. However, the high risk of a cross-firing effect exists if the $\mathrm{mAb}$ is labeled with a radioactive radionuclide, particularly in the case of long-range $\beta$-emitters like ${ }^{131} \mathrm{I}$ or ${ }^{90} \mathrm{Y}$. Pharmacokinetics values can be improved by pre-targeting [91]. The idea behind this is that the labeled antibodies, in intact or in fragmented form to reduce their molecular size, or in the form of recombinant, function to carry bounded radionuclides to the tumor site. The multistep pre-targeting radio immunotherapy method first delivers antibodies by using the streptavidin method or biotin-avidin method, or by the use of bispecific antibodies, thus allowing considerable time for the excess $\mathrm{mAb}$ to eliminate. This is followed by the radiolabeled heptane to be directed toward the mAbs. As such, the time for the radioactivity to spread toxicity is constrained, becoming more efficacious in therapeutic levels. Bispecific haptens engineering allows cooperative binding, so two different antigen scan be targeted by incorporating two different antibodies. Examples of pre-targeted RIT in reported studies are listed in Table 3.

Table 3. Examples of studies of pre-targeting RIT alone and in combination therapy with pre-targeted RIT studies.

\begin{tabular}{|c|c|c|c|c|c|c|}
\hline Aim & Radionuclide & Cancer Type & $\begin{array}{l}\text { Targeted } \\
\text { Antigen }\end{array}$ & Subject & Combination & Reference \\
\hline $\begin{array}{l}\text { To determine maximum tolerated dose } \\
\text { and antitumor efficacy of three-step } \\
\text { pre-targeting method }\end{array}$ & ${ }^{90} \mathrm{Y}$ & Glioma & Tenascin & Human & No & [92] \\
\hline $\begin{array}{l}\text { Safe and effective with negligible } \\
\text { toxicity pre-targeting RIT }\end{array}$ & ${ }^{90} \mathrm{Y}$ & $\begin{array}{l}\text { LS-180, human } \\
\text { carcinoma }\end{array}$ & Ep-CAM & $\begin{array}{l}\mathrm{BALB} / \mathrm{c} \\
\text { nude mice }\end{array}$ & No & [93] \\
\hline
\end{tabular}

\section{Conclusions}

RIT for solid tumors may be efficacious after modulation of barriers. Therefore, strategies and approaches should be implemented to achieve RIT application in clinical studies. Evidence from both animal and clinical studies have highlighted the importance of combination RIT, as it can overcome various internal and external barriers and clear the pathway for $\mathrm{mAb}$ penetration into solid tumors, thus improving the efficacy of conventional RIT.

Author Contributions: Conceptualization, J.S.K.; writing-original draft preparation, J.Z. and H.K.; writing-review and editing, J.S.K.; funding acquisition, Y.-J.L. and S.M.L.; proofreading, Y.-J.L. and S.M.L.

Funding: This study was supported by a grant from the Korea Institute of Radiological and Medical Sciences (KIRAMS), funded by the Ministry of Science and ICT (MSIT), Republic of Korea (No. 50461-2019, PI: Kyo Chul Lee; 50536-2019, PI: Yong Jin Lee).

Conflicts of Interest: The authors declare no conflict of interest. The funders had no role in the design of the study; in the collection, analyses, or interpretation of data; in the writing of the manuscript; or in the decision to publish the results. 


\section{Abbreviations}

$\begin{array}{ll}\text { RIT } & \text { Radioimmunotherapy } \\ \mathrm{mAb} & \text { Monoclonal Antibody } \\ \text { ADCC } & \text { Antibody-dependent cellular cytotoxicity } \\ \text { ADCP } & \text { Antibody-dependent cellular phagocytosis } \\ \text { MAC } & \text { Membrane attack complex } \\ \text { CDC } & \text { Complement-dependent cytotoxicity } \\ \text { PI3K } & \text { Phosphatidylinositol 3-kinase } \\ \text { PLCv } & \text { Phospholipase v } \\ \text { PKC } & \text { Protein kinase C } \\ \text { MAPK } & \text { Mitogen activated protein kinase } \\ \text { KRAS } & \text { Kristen rat sarcoma } \\ \text { CMC } & \text { Cell-mediated cytotoxicity }\end{array}$

\section{References}

1. Boiardi, A.; Bartolomei, M.; Silvani, A.; Eoli, M.; Salmaggi, A.; Lamperti, E.; Milanesi, I.; Botturi, A.; Rocca, P.; Bodei, L.; et al. Intratumoral delivery of mitoxantrone in association with 90-Y radioimmunotherapy (RIT) in recurrent glioblastoma. J. Neuro Oncol. 2005, 72, 125-131. [CrossRef] [PubMed]

2. Dietlein, M.; Dressler, J.; Farahati, J.; Leisner, B.; Moser, E.; Reiners, C.; Schicha, H.; Schober, O. Guidelines for radioiodine therapy (RIT) in differentiated thyroid cancer. Nuklearmedizin 1999, 38, 221-222. [PubMed]

3. Dietlein, M.; Dressler, J.; Joseph, K.; Leisner, B.; Moser, E.; Reiners, C.; Schicha, H.; Schneider, P.; Schober, O. Guidelines for radioiodine therapy (RIT) in benign thyroid diseases. Nuklearmedizin 1999, 38, 219-220. [PubMed]

4. Kim, J.S. Combination Radioimmunotherapy Approaches and Quantification of Immuno-PET. Nucl. Med. Mol. Imaging 2016, 50, 104-111. [CrossRef] [PubMed]

5. Kraeber-Bodéré, F.; Barbet, J.; Chatal, J.F. Radioimmunotherapy: From Current Clinical Success to Future Industrial Breakthrough? J. Nucl. Med. 2018, 115, 329-331. [CrossRef]

6. Larson, S.M.; Carrasquillo, J.A.; Cheung, N.V.; Press, O.W. Radioimmunotherapy of human tumours. Nat. Rev. Cancer 2015, 15, 347-360. [CrossRef]

7. Jacene, H.; Crandall, J.; Kasamon, Y.L.; Ambinder, R.F.; Piantadosi, S.; Serena, D.; Kasecamp, W.; Wahl, R.L. Initial Experience with Tositumomab and I-131-Labeled Tositumomab for Treatment of Relapsed/Refractory Hodgkin Lymphoma. Mol. Imaging Biol. 2017, 19. [CrossRef]

8. Lim, I.; Park, J.Y.; Kang, H.J.; Hwang, J.P.; Lee, S.S.; Kim, K.M.; Choi, T.H.; Yang, S.H.; Kim, B.I.; Choi, C.W.; et al. Prognostic significance of pretreatment F-18-FDG PET/CT in patients with relapsed/refractory B-cell non-Hodgkin's lymphoma treated by radioimmunotherapy using I-131-rituximab. Acta Haematol. 2013, 130, 74-82. [CrossRef]

9. Provencio, M.F.F.; Gómez-Codina, J.; Quero Blanco, C.; Llanos, M.; Garcia-Arroyo, F.; de la Cruz, L.; Gumá, J.; Delgado, J.R.; Álvarez, R.; Chacón, J.I.; et al. Consolidation treatment with yttrium-90 ibritumomab tiuxetan after new induction regimen in advanced stage follicular lymphoma: Update results from the Spanish Lymphoma Oncology Group trial after a median follow-up of 8.5-years. Leuk. Lymphoma 2018, 20, 1-4. [CrossRef]

10. Puronen, C.E.; Cassaday, R.D.; Stevenson, P.A.; Sandmaier, B.M.; Flowers, M.E.; Green, D.J.; Maloney, D.G.; Storb, R.F.; Press, O.W.; Gopal, A.K. Long-Term Follow-Up of Y-90-Ibritumomab Tiuxetan, Fludarabine, and Total Body Irradiation-Based Nonmyeloablative Allogeneic Transplant Conditioning for Persistent High-Risk B Cell Lymphoma. Biol. Blood Marrow Transplant. 2018, 24, 2211-2215. [CrossRef]

11. Thurber, G.M.; Schmidt, M.M.; Wittrup, K.D. Factors determining antibody distribution in tumors. Trends Pharmacol. Sci. 2008, 29, 57-61. [CrossRef] [PubMed]

12. Ocean, A.J.; Pennington, K.L.; Guarino, M.J.; Sheikh, A.; Bekaii-Saab, T.; Serafini, A.N.; Lee, D.; Sung, M.W.; Gulec, S.A.; Goldsmith, S.J.; et al. Fractionated radioimmunotherapy with Y-90- clivatuzumab tetraxetan and low-dose gemcitabine is active in advanced pancreatic cancer: A phase 1 trial. Cancer 2012, 118, 5497-5506. [CrossRef] [PubMed] 
13. Forero-Torres, A.; Shen, S.; Breitz, H.; Sims, R.B.; Axworthy, D.B.; Khazaeli, M.B.; Chen, K.H.; Percent, I.; Besh, S.; LoBuglio, A.F.; et al. Pretargeted radioimmunotherapy (RIT) with a novel anti-TAG-72 fusion protein. Cancer Biother. Radiopharm. 2005, 20, 379-390. [CrossRef] [PubMed]

14. Buchsbaum, D.J. CD38 pretargeted RIT of B-cell tumors. Blood 2018, 131, 589-590. [CrossRef] [PubMed]

15. Zhang, S.; Xing, J.; Zhang, Q.; Song, F.; Li, Y.; Yang, X.; Chen, Z. Optimal design of Ig 5' primers for construction of diverse phage antibody library established to select anti-HAb18GEF and anti-DOTA-Y Fabs for hepatoma pretargeting RIT. Front. Biosci. 2006, 11, 1733-1749. [CrossRef] [PubMed]

16. DeNardo, S.J.; DeNardo, G.L.; Brush, J.; Carter, P. Phage library-derived human anti-TETA and anti-DOTA ScFv for pretargeting RIT. Hybridoma 1999, 18, 13-21. [CrossRef]

17. Orlova, A.; Jonsson, A.; Rosik, D.; Lundqvist, H.; Lindborg, M.; Abrahmsen, L.; Ekblad, C.; Frejd, F.Y.; Tolmachev, V. Site-Specific Radiometal Labeling and Improved Biodistribution Using ABY-027, A Novel HER2-Targeting Affibody Molecule-Albumin-Binding Domain Fusion Protein. J. Nucl. Med. 2013, 54, 961-968. [CrossRef]

18. Frost, S.H.; Back, T.; Chouin, N.; Hultborn, R.; Jacobsson, L.; Elgqvist, J.; Jensen, H.; Albertsson, P.; Lindegren, S. Comparison of At-211-PRIT and At-211 RIT of ovarian microtumors in a nude mouse model. Cancer Biother. Radiopharm. 2013, 28, 108-114. [CrossRef]

19. Suzuki, M.; Kato, C.; Kato, A. Therapeutic antibodies: Their mechanisms of action and the pathological findings they induce in toxicity studies. J. Toxicol. Pathol. 2015, 28, 133-139. [CrossRef]

20. Hudis, C.A. Trastuzumab-Mechanism of Action and Use in Clinical Practice. N. Engl. J. Med. 2007, 357, 39-51. [CrossRef]

21. Weiner, G.J. Rituximab: Mechanism of Action. Semin. Hematol. 2010, 47, 115-123. [CrossRef] [PubMed]

22. Weiner, L.M.; Dhodapkar, M.V.; Ferrone, S. Monoclonal antibodies for cancer immunotherapy. Lancet 2009, 373, 1033-1040. [CrossRef]

23. Cavallo, F.; Calogero, R.A.; Forni, G. Are oncoantigens suitable targets for anti-tumour therapy? Nat. Rev. Cancer 2007, 7, 707. [CrossRef] [PubMed]

24. Wang, S.-Y.; Racila, E.; Taylor, R.P.; Weiner, G.J. NK-cell activation and antibody-dependent cellular cytotoxicity induced by rituximab-coated target cells is inhibited by the C3b component of complement. Blood 2008, 111, 1456-1463. [CrossRef]

25. Gül, N.; van Egmond, M. Antibody-Dependent Phagocytosis of Tumor Cells by Macrophages: A Potent Effector Mechanism of Monoclonal Antibody Therapy of Cancer. Cancer Res. 2015, 75, 5008-5013. [CrossRef]

26. Lopez, J.A.; Susanto, O.; Jenkins, M.R.; Lukoyanova, N.; Sutton, V.R.; Law, R.H.P.; Johnston, A.; Bird, C.H.; Bird, P.I.; Whisstock, J.C.; et al. Perforin forms transient pores on the target cell plasma membrane to facilitate rapid access of granzymes during killer cell attack. Blood 2013, 121, 2659-2668. [CrossRef]

27. Shresta, S.; MacIvor, D.M.; Heusel, J.W.; Russell, J.H.; Ley, T.J. Natural killer and lymphokine-activated killer cells require granzyme B for the rapid induction of apoptosis in susceptible target cells. Proc. Natl. Acad. Sci. USA 1995, 92, 5679-5683. [CrossRef]

28. Patrick, M.; Glassman, J.P.B. Mechanistic considerations for the use of monoclonal antibodies for cancer therapy. Cancer Biol. Med. 2014, 11, 20-33.

29. Vu, T.; Claret, F.X. Trastuzumab: Updated mechanisms of action and resistance in breast cancer. Front. Oncol. 2012, 2. [CrossRef]

30. Ellis, L.M. Mechanisms of Action of Bevacizumab as a Component of Therapy for Metastatic Colorectal Cancer. Semin. Oncol. 2006, 33, S1-S7. [CrossRef]

31. Hecht, J.R.; Mitchell, E.; Chidiac, T.; Scroggin, C.; Hagenstad, C.; Spigel, D.; Marshall, J.; Cohn, A.; McCollum, D.; Stella, P.; et al. A Randomized Phase IIIB Trial of Chemotherapy, Bevacizumab, and Panitumumab Compared with Chemotherapy and Bevacizumab Alone for Metastatic Colorectal Cancer. J. Clin. Oncol. 2009, 27, 672-680. [CrossRef] [PubMed]

32. Tol, J.; Koopman, M.; Cats, A.; Rodenburg, C.J.; Creemers, G.J.M.; Schrama, J.G.; Erdkamp, F.L.G.; Vos, A.H.; van Groeningen, C.J.; Sinnige, H.A.M.; et al. Chemotherapy, Bevacizumab, and Cetuximab in Metastatic Colorectal Cancer. N. Engl. J. Med. 2009, 360, 563-572. [CrossRef] [PubMed]

33. Al Tameemi, W.; Dale, T.P.; Al-Jumaily, R.M.K.; Forsyth, N.R. Hypoxia-Modified Cancer Cell Metabolism. Front. Cell Dev. Biol. 2019, 7. [CrossRef] [PubMed] 
34. Benjamin, L.E.; Golijanin, D.; Itin, A.; Pode, D.; Keshet, E. Selective ablation of immature blood vessels in established human tumors follows vascular endothelial growth factor withdrawal. J. Clin. Investig. 1999, 103, 159-165. [CrossRef] [PubMed]

35. Inai, T.; Mancuso, M.; Hashizume, H.; Baffert, F.; Haskell, A.; Baluk, P.; Hu-Lowe, D.D.; Shalinsky, D.R.; Thurston, G.; Yancopoulos, G.D.; et al. Inhibition of Vascular Endothelial Growth Factor (VEGF) Signaling in Cancer Causes Loss of Endothelial Fenestrations, Regression of Tumor Vessels, and Appearance of Basement Membrane Ghosts. Am. J. Pathol. 2004, 165, 35-52. [CrossRef]

36. Jang, B.S.; Lee, S.M.; Kim, H.S.; Shin, I.S.; Razjouyan, F.; Wang, S.; Yao, Z.; Pastan, I.; Dreher, M.R.; Paik, C.H. Combined-modality radioimmunotherapy: Synergistic effect of paclitaxel and additive effect of bevacizumab. Nucl. Med. Biol. 2012, 39, 472-483. [CrossRef]

37. Arjaans, M.; Oude Munnink, T.H.; Oosting, S.F.; Terwisscha van Scheltinga, A.G.T.; Gietema, J.A.; Garbacik, E.T.; Timmer-Bosscha, H.; Lub-de Hooge, M.N.; Schröder, C.P.; de Vries, E.G.E. Bevacizumab-Induced Normalization of Blood Vessels in Tumors Hampers Antibody Uptake. Cancer Res. 2013, 73, 3347-3355. [CrossRef]

38. Shibuya, M. Vascular Endothelial Growth Factor (VEGF) and Its Receptor (VEGFR) Signaling in Angiogenesis: A Crucial Target for Anti- and Pro-Angiogenic Therapies. Genes Cancer 2011, 2, 1097-1105. [CrossRef]

39. Zhuang, H.; Xue, Z.; Wang, L.; Li, X.; Zhang, N.; Zhang, R. Efficacy and Immune Mechanisms of Cetuximab for the Treatment of Metastatic Colorectal Cancer. Clin. Oncol. Cancer Res. 2011, 8, 207-214. [CrossRef]

40. Vincenzi, B.; Santini, D.; Tonini, G. New Issues on Cetuximab Mechanism of Action in Epidermal Growth Factor Receptor-Negative Colorectal Cancer: The Role of Vascular Endothelial Growth Factor. J. Clin. Oncol. 2006, 24, 1957-1965. [CrossRef]

41. Topalian, S.L.; Drake, C.G.; Pardoll, M. Immune Checkpoint Blockade: A CommonDenominator Approach to Cancer Therapy. Cancer Cell 2015, 27, 450-460. [CrossRef] [PubMed]

42. Andrade de Mello, R.; Flávia Veloso, A.; Esrom Catarina, P.; Nadine, S.; Antoniou, G. Potential role of immunotherapy in advanced non-small-cell lung cancer. Oncol. Targets Ther. 2016, 10, 21-30. [CrossRef] [PubMed]

43. Khaibullina, A.; Jang, B.S.; Sun, H.; Le, N.; Yu, S.; Frenkel, V.; Carrasquillo, J.A.; Pastan, I.; Li, K.C.; Paik, C.H. Pulsed high-intensity focused ultrasound enhances uptake of radiolabeled monoclonal antibody to human epidermoid tumor in nude mice. J. Nucl. Med. 2008, 49, 295-302. [CrossRef]

44. Pickup, M.W.; Mouw, J.K.; Weaver, V.M. The extracellular matrix modulates the hallmarks of cancer. EMBO Rep. 2014, 2014, 1243-1253. [CrossRef]

45. González-Mariscal, L.; Betanzos, A.; Nava, P.; Jaramillo, B.E. Tight junction proteins. Prog. Biophys. Mol. Biol. 2003, 81, 1-44. [CrossRef]

46. Alain, P.; Boucher, Y.; Saroja, R.; McKee, T.D.; Gohongi, T.; Emmanuelle di, T.; Brown, E.B.; Yotaro, I.; Campbell, R.B.; Berk, D.A.; et al. Role of tumor-host interactions in interstitial diffusion of macromolecules: Cranial vs. subcutaneous tumors. Proc. Natl. Acad. Sci. USA 2001, 98, 4628-4633.

47. Navarro-Teulon, I.; Lozza, C.; Pèlegrin, A.; Vivès, E.; Pouget, J.P. General overview of radioimmunotherapy of solid tumors. Immunotherapy 2013, 5, 467-487. [CrossRef]

48. Marc, Y.; David, A.; Cathy, M.; Patrick, F.; François, Q.; Bernard, S.-A.; Philippe, R.; Monique, P.; Caroline, B.-M.; Dominique, G.; et al. Adjuvant Radioimmunotherapy Trialwith Iodine-131^ Labeled Anti Carcinoembryonic AntigenMonoclonal Antibody F6 F(abII)2 after Resection of LiverMetastases from Colorectal Cancer. Clin. Cancer Res. 2008, 14, 3487-3493.

49. Crittenden, M.; Kohrt, H.; Levy, R.; Jones, J.; Camphausen, K.; Dicker, A.; Demaria, S.; Formenti, S. Current Clinical Trials Testing Combinations of Immunotherapy and Radiation. Semin. Radiat. Oncol. 2015, 25, 54-64. [CrossRef]

50. Lu, P.; Weaver, V.M.; Werb, Z. The extracellular matrix: A dynamic niche in cancer progression. J. Cell Biol. 2018, 196, 395-406. [CrossRef]

51. Hu, G.; Li, L.; Xu, W. Extracellular matrix in mammary gland development and breast cancer progression. Front. Lab. Med. 2017, 1, 36-39. [CrossRef]

52. Netti, P.A.; Berk, D.A.; Swartz, M.A.; Grodzinsky, A.J.; Jain, R.K. Role of Extracellular Matrix Assembly in Interstitial Transport in Solid Tumors. Cancer Res. 2000, 60, 2497-2503. [PubMed] 
53. Live Eikenes, Ø.S.B.; Christian, B.; Catharina de Lange, D. Collagenase Increases the Transcapillary Pressure Gradient and Improves the Uptake and Distribution of Monoclonal Antibodies in Human Osteosarcoma Xenografts. Cancer Res. 2004, 64, 4768-4773. [CrossRef] [PubMed]

54. Váradi, T.; Mersich, T.; Auvinen, P.; Tammi, R.; Tammi, M.; Salamon, F.; Besznyák, I., Jr.; Jakab, F.; Baranyai, Z.; Szöllősi, J.; et al. Binding of trastuzumab to ErbB2 is inhibited by a high pericellular density of hyaluronan. J. Histochem. Cytochem. 2012, 60, 567-575. [CrossRef]

55. Pan, A.; Wang, Z.; Chen, B.; Dai, W.; Zhang, H.; He, B.; Wang, X.; Wang, Y.; Zhang, Q. Localized co-delivery of collagenase and trastuzumab by thermosensitive hydrogels for enhanced antitumor efficacy in human breast xenograft. Drug Deliv. 2018, 25, 1495-1503. [CrossRef]

56. Chon, H.J.; Lee, W.S.; Yang, H.; Kong, S.J.; Lee, N.K.; Moon, E.S.; Choi, J.; Han, E.C.; Kim, J.H.; Ahn, J.B.; et al. Tumor Microenvironment Remodeling by Intratumoral Oncolytic Vaccinia Virus Enhances the Efficacy of Immune-Checkpoint Blockade. Clin. Cancer Res. 2019, 25, 1612-1623. [CrossRef]

57. Anderson, J.M.; Van Itallie, C.M. Physiology and function of the tight junction. Cold Spring Harb. Perspect. Biol. 2009, 1, a002584. [CrossRef]

58. Ines, B.; Hua, C.; Jonas, P.; Roma, Y.; Andre, L. A New Epithelial Junction Opener for Cancer Therapy. Mol. Ther. 2013, 21, S78-S79.

59. Wang, H.; Li, Z.-Y.; Liu, Y.; Persson, J.; Beyer, I.; Möller, T.; Koyuncu, D.; Drescher, M.R.; Strauss, R.; Zhang, X.-B.; et al. Desmoglein 2 is a receptor for adenovirus serotypes 3, 7, 11 and 14. Nat. Med. 2010, 17, 96. [CrossRef]

60. Heldin, C.H.; Rubin, K.; Pietras, K.; Ostman, A. High Interstitial Fluid Pressure-An Obstacle In Cancer Therapy. Nature 2004, 4, 806-813. [CrossRef]

61. Jain, R.K.; Martin, J.D.; Stylianopoulos, T. The role of mechanical forces in tumor growth and therapy. Annu. Rev. Biomed. Eng. 2014, 16, 321-346. [CrossRef] [PubMed]

62. Wolff, A.C.; Hammond, M.E.; Schwartz, J.N.; Hagerty, K.L.; Allred, D.C.; Cote, R.J.; Dowsett, M.; Fitzgibbons, P.L.; Hanna, W.M.; Langer, A.; et al. American Society of Clinical Oncology/College of American Pathologists guideline recommendations for human epidermal growth factor receptor 2 testing in breast cancer. J. Clin. Oncol. 2007, 25, 118-145. [CrossRef] [PubMed]

63. Provenzano, P.P.; Cuevas, C.; Chang, A.E.; Goel, V.K.; Von Hoff, D.D.; Hingorani, S.R. Enzymatic targeting of the stroma ablates physical barriers to treatment of pancreatic ductal adenocarcinoma. Cancer Cell 2012, 21, 418-429. [CrossRef] [PubMed]

64. Stylianopoulos, T.; Munn, L.L.; Jain, R.K. Reengineering the Tumor Vasculature: Improving Drug Delivery and Efficacy. Trends Cancer 2018, 4, 258-259. [CrossRef] [PubMed]

65. Jain, R.K. Transport of Molecules in the Tumor Interstitium: A Review. Cancer Res. 1987, 47, 3039-3051. [PubMed]

66. Young, J.S.; Llumsden, C.E.; Stalker, A.L. The significance of the "tissue pressure" of normal testicular and of neoplastic (Brown-Pearce carcinoma) tissue in the rabbit. J. Pathol. Bacteriol. 1950, 62, 313-333. [CrossRef]

67. Li, T.; Wang, Y.N.; Khokhlova, T.D.; D'Andrea, S.; Starr, F.; Chen, H.; McCune, J.S.; Risler, L.J.; Mashadi-Hossein, A.; Hingorani, S.R.; et al. Pulsed high intensity focused ultrasound (pHIFU) enhances delivery of doxorubicin in a preclinical model of pancreatic cancer. Cancer Res. 2015, 75, 3738-3746. [CrossRef]

68. Wang, S.; Shin, I.S.; Hancock, H.; Jang, B.-S.; Kim, H.-S.; Lee, S.M.; Zderic, V.; Frenkel, V.; Pastan, I.; Paik, C.H.; et al. Pulsed high intensity focused ultrasound increases penetration and therapeutic efficacy of monoclonal antibodies in murine xenograft tumors. J. Control. Release 2012, 162, 218-224. [CrossRef]

69. Griffon-Etienne, G.; Boucher, Y.; Brekken, C.; Suit, H.D.; Jain, R.K. Taxane-induced Apoptosis Decompresses Blood Vessels and Lowers Interstitial Fluid Pressure in Solid Tumors. Clin. Implic. 1999, 59, 3776-3782.

70. De Souza, A.P.; Bonorino, C. Tumor immunosuppressive environment: Effects on tumor-specific and nontumor antigen immune responses. Expert Rev. Anticancer Ther. 2009, 9, 1317-1332. [CrossRef]

71. Freeman, G.J.; Long, A.J.; Iwai, Y.; Bourque, K.; Chernova, T.; Nishimura, H.; Fitz, L.J.; Malenkovich, N.; Okazaki, T.; Byrne, M.C.; et al. Engagement of the PD-1 immunoinhibitory receptor by a novel B7 family member leads to negative regulation of lymphocyte activation. J. Exp. Med. 2000, 192, 1027-1034. [CrossRef] [PubMed]

72. Nagarsheth, N.; Wicha, M.S.; Zou, W. Chemokines in the cancer microenvironment and their relevance in cancer immunotherapy. Nat. Rev. Immunol. 2017, 17, 559. [CrossRef] [PubMed]

73. Sherr, C.J. Principles of Tumor Suppression. Cell 2004, 116, 235-246. [CrossRef] 
74. Azad, A.; Yin Lim, S.; D'Costa, Z.; Jones, K.; Diana, A.; Sansom, O.J.; Kruger, P.; Liu, S.; McKenna, W.G.; Dushek, O.; et al. PD-L1 blockade enhances response of pancreatic ductal adenocarcinoma to radiotherapy. EMBO Mol. Med. 2017, 9, 167-180. [CrossRef]

75. Vanpouille-Box, C.; Formenti, S.C.; Demaria, S. Toward Precision Radiotherapy for Use with Immune Checkpoint Blockers. Clin. Cancer Res. 2018, 24, 259-265. [CrossRef]

76. Rockwell, S.; Dobrucki, I.T.; Kim, E.Y.; Marrison, S.T.; Vu, V.T. Hypoxia and radiation therapy: Past history, ongoing research, and future promise. Curr. Mol. Med. 2009, 9, 442-458. [CrossRef]

77. Hall, E.J.; Giaccia, A.J. Radiobiology for the Radiologist; Lippincott Williams \& Wilkins: Philadelphia, PA, USA, 2010; pp. 92-93.

78. Krock, B.L.; Skuli, N.; Simon, M.C. Hypoxia-induced angiogenesis: Good and evil. Genes Cancer 2011, 2, 1117-1133. [CrossRef]

79. Muz, B.; de la Puente, P.; Azab, F.; Azab, A.K. The role of hypoxia in cancer progression, angiogenesis, metastasis, and resistance to therapy. Hypoxia 2015, 3, 83-92. [CrossRef]

80. Hashimoto, T.; Shibasaki, F. Hypoxia-inducible factor as an angiogenic master switch. Front. Pediatr. 2015, 3, 33. [CrossRef]

81. Harada, H.; Kizaka-Kondoh, S.; Li, G.; Itasaka, S.; Shibuya, K.; Inoue, M.; Hiraoka, M. Significance of HIF-1-active cells in angiogenesis and radioresistance. Oncogene 2007, 26, 7508-7516. [CrossRef]

82. Xu, S.; Tang, Y.Y.; Yu, Y.X.; Yun, Q.; Yang, J.P.; Zhang, H.; Peng, Q.; Sun, X.; Yang, L.L.; Fu, S.; et al. Novel composite drug delivery system as a novel radio sensitizer for the local treatment of cervical carcinoma. Drug Deliv. 2017, 24, 1139-1147. [CrossRef] [PubMed]

83. Ng, B.; Kramer, E.; Liebes, L.; Wasserheit, C.; Hochster, H.; Blank, E.; Ceriani, R.; Furmanski, P. Radiosensitization of Tumor-targeted Radioimmunotherapy with Prolonged Topotecan Infusion in Human Breast Cancer Xenografts. Cancer Res. 2001, 61, 2996-3001. [PubMed]

84. Milenic, D.E.; Garmestani, K.; Brady, E.D.; Albert, P.S.; Abdulla, A.; Flynn, J.; Brechbiel, M.W. Potentiation of High-LET Radiation by Gemcitabine:Targeting HER2 withTrastuzumab toTreat Disseminated Peritoneal Disease. Clin. Cancer Res. 2007, 13, 1926-1935. [CrossRef] [PubMed]

85. Yong, K.J.; Milenic, D.E.; Baidoo, K.E.; Brechbiel, M.W. Impact of a-Targeted Radiation Therapy on Gene Expression in a Pre-Clinical Model for Disseminated Peritoneal Disease when Combined with Paclitaxel. PLOS ONE 2014, 9, e108511. [CrossRef]

86. Cividalli, A.; Arcangeli, G.; Cruciani, G.; Livdi, E.; Cordelli, E.; Danesi, D.T. Enhancement of Radiation Response by Paclitaxel in Mice According to Different Treatment Schedules. Int. J. Radiat. Oncol. Biol. Phys. 1998, 40, 1163-1170. [CrossRef]

87. Kelly, M.P.; Lee, F.T.; Smyth, F.E.; Brechbiel, M.W.; Scott, A.M. Enhanced Efficacy of 90Y-Radiolabeled Anti-Lewis Y Humanized Monoclonal Antibody hu3S193 and Paclitaxel Combined-Modality Radioimmunotherapy in a Breast Cancer Model. J. Nucl. Med. 2018, 47, 716-725.

88. Kurizaki, T.; Okazaki, S.; Sanderson, S.D.; Colcher, D.; Enke, C.A.; Tempero, M.A.; Baranowska-Kortylewicz, J. Potentiation of Radioimmunotherapy with Response-Selective Peptide Agonist of Human C5a. J. Nucl. Med. 2002, 43, 957-967.

89. Koppe, M.J.; Oyen, W.J.; Bleichrodt, R.P.; Hendriks, T.; Verhofstad, A.A.; Goldenberg, D.M.; Boerman, O.C. Combination therapy using the cyclooxygenase-2 inhibitor Parecoxib and radioimmunotherapy in nude mice with small peritoneal metastases of colonic origin. Cancer Immunol. Immunother. 2006, 55, 47-55. [CrossRef]

90. Kosaka, A.; Ohkuri, T.; Okada, H. Combination of an agonistic anti-CD40 monoclonal antibody and the COX-2 inhibitor celecoxib induces anti-glioma effects by promotion of type- 1 immunity in myeloid cells and T-cells. Cancer Immunol. Immunother. 2014, 63, 847-857. [CrossRef]

91. Reilly, R.M. Radioimmunotherapy of Solid Tumors: The Promise of Pretargeting Strategies Using Bispecific Antibodies and Radiolabeled Haptens. J. Nucl. Med. 2006, 47, 196-199.

92. Paganelli, G.; Bartolomei, M.; Ferrari, M.; Cremonesi, M.; Broggi, G.; Maira, C.; Sturiale, C.; Grana, C.; Prisco, G.; Gatti, M.; et al. Pre-Targeted Locoregional Radioimmunotherapy with 90Y-biotin in Glioma Patients: Phase I Study and Preliminary Therapeutic Results. Cancer Biother. Radiopharm. 2001, 16, 227-235. [CrossRef] 
93. Axworthy, D.B.; Reno, J.M.; Hylarides, M.D.; Mallett, R.W.; Theodore, L.J.; Gustavson, L.M.; Su, F.; Hobson, L.J.; Beaumier, P.L.; Fritzberg, A.R. Cure of human carcinoma xenografts by a single dose of pretargeted Y-90 with negligible toxicity. Proc. Natl. Acad. Sci. USA 2000, 97, 1802-1807. [CrossRef] [PubMed]

94. Graves, S.S.; Dearstyne, E.; Lin, Y.; Zuo, Y.; Sanderson, J.; Schultz, J.; Pantalias, A.; Gray, D.; Axworthy, D.; Jones, H.M.; et al. Combination Therapy with Pretarget CC49 Radioimmunotherapy and Gemcitabine Prolongs Tumor Doubling Time in a Murine Xenograft Model of Colon Cancer More Effectively Than Either Monotherapy. Clin. Cancer Res. 2003, 9, 3712-3721. [PubMed]

(C) 2019 by the authors. Licensee MDPI, Basel, Switzerland. This article is an open access article distributed under the terms and conditions of the Creative Commons Attribution (CC BY) license (http://creativecommons.org/licenses/by/4.0/). 